\title{
Germline prognostic markers for urinary bladder cancer
}

Citation for published version (APA):

Lipunova, N. (2020). Germline prognostic markers for urinary bladder cancer. [Doctoral Thesis, Maastricht University]. Maastricht University. https://doi.org/10.26481/dis.20201112nl

Document status and date:

Published: 01/01/2020

DOI:

10.26481/dis.20201112nl

Document Version:

Publisher's PDF, also known as Version of record

\section{Please check the document version of this publication:}

- A submitted manuscript is the version of the article upon submission and before peer-review. There can be important differences between the submitted version and the official published version of record.

People interested in the research are advised to contact the author for the final version of the publication, or visit the DOI to the publisher's website.

- The final author version and the galley proof are versions of the publication after peer review.

- The final published version features the final layout of the paper including the volume, issue and page numbers.

Link to publication

\footnotetext{
General rights rights.

- You may freely distribute the URL identifying the publication in the public portal. please follow below link for the End User Agreement:

www.umlib.nl/taverne-license

Take down policy

If you believe that this document breaches copyright please contact us at:

repository@maastrichtuniversity.nl

providing details and we will investigate your claim.
}

Copyright and moral rights for the publications made accessible in the public portal are retained by the authors and/or other copyright owners and it is a condition of accessing publications that users recognise and abide by the legal requirements associated with these

- Users may download and print one copy of any publication from the public portal for the purpose of private study or research.

- You may not further distribute the material or use it for any profit-making activity or commercial gain

If the publication is distributed under the terms of Article $25 \mathrm{fa}$ of the Dutch Copyright Act, indicated by the "Taverne" license above, 


\begin{abstract}
The majority of urinary bladder cancer (UBC) cases are diagnosed as non-muscle invasive malignancies, having a favourable prognosis in terms of overall 5-year survival. However, non-muscle invasive bladder cancer (NMIBC) cases show high recurrence and progression rates and inconsistencies within the NMIBC risk group, resulting in a substantial burden on patients and health systems.

The evidence for genetic risk factors having a role in NMIBC susceptibility and prognosis make NMIBC a good candidate for personalised medicine approaches; however, multiple genome-wide association studies (GWAS) have primarily focused on NMIBC risk alone, even though investigating prognostic factors would arguably yield more benefit.

It is recognised that genetic variation contributes to complex traits in the form of multiple effects of low-penetrance, as well as interacting not only with each other, but with various environmental factors as well, resulting in a complex problem to resolve. In a setting of a bladder cancer patient cohort, our project aims to identify genetic variants of genome-wide significance that might be associated with certain NMIBC characteristics at diagnosis, and potential gene-environment interaction effects with smoking. Furthermore, we aim to address the importance of replication in genetic association studies by utilising a resource of UK Biobank, whilst introducing a novel approach for identifying prognostic events from routinely collected data.

In conclusion, the current thesis provides additional evidence to the field of bladder cancer genetics and suggests further research topics of interest that could lead to optimising NMIBC patients' care.
\end{abstract}

